\title{
Responsabilidade Penal da Pessoa Jurídica: Efetividade e Questões Processuais
}

\author{
Eládio Lecey ${ }^{1}$
}

\section{RESPONSABILIDADE PENAL DA PESSOA JURÍDICA. DIREITO AMBIENTAL PENAL: UMNOVO PARADIGMA?}

O bem juridicamente tutelado pelo Direito Ambiental Penal é o próprio meio ambiente e um bem difuso por excelência. O meio ambiente é um bem acentuadamente difuso. Uma ofensa ao ambiente, embora reflexamente e por vezes de maneira imediata possa atentar contra direitos individuais, como a vida e a saúde das pessoas, atenta contra a coletividade e incide difusamente, dizendo não somente com as geraçöes presentes, mas com as futuras geraçōes, consoante muito bem aponta a nossa Constituição Federal que, em seu artigo 225, determina que "Todos têm direito ao meío ambiente ecologicamente equilibrado, bem de uso comum do povo e essencial à sadia qualidade de vida, impondo-se ao Poder Público è coletividade o dever de defendê-lo e preservá-lo para as presentes e futuras geraçoes".

Na verdade, o meio ambiente é mais do que um direito, um autêntico interesse. Como observa Mancuso, um direito esgota sua função "a partir do momento em que outorga uma prerrogativa a seu titular, enquanto o interesse tende a, indefinidamente, se repetir e a se transformar. ${ }^{2}$.

O meio ambiente é um bem, um autêntico valor, ou melhor, uma riqueza, em si, gerando interesses às pessoas individual e coletivamente consideradas.

De tal peculiaridade, emergem suas características como um bem e interesse autônomo, supraindividual e com âmbito macrossocial.

Ditas características especiais do bem tutelado pela norma ambiental penal, reflexos tiveram no Direito Ambiental Penal, de modo a diferenciá-lo do direito penal tradicional, acentuando-se a prevenção geral, com adoção de tipos de perigo a fim de serem atingidos os riscos, o caráter educativo, com tipos dotados de elementos normativos e até normas penais em branco, considerada também a interdisciplinaridade da questão ambiental e a prevenção especial com tipos culposos, omissivos e até omissivos culposos.

\footnotetext{
1 Presidente do Instituto "O Direito por um Planeta Verde"; Professor das Escolas da Magistratura e do Ministério Público do Rio Grande do Sul

${ }^{2}$ Mancuso, Rodolfo de Camargo, Interesses Difusos, Conceito e legitimação para agir, Editora RT, $5 a$. ed.,2000 p. 97
} 
Novos paradigmas se fizeram necessários e, dentre eles, destaca-se a responsabilização criminal da pessoa jurídica, tendo em vista as mais expressivas degradaçoes a promanarem na sociedade de massa e de risco da atualidade, através e no interesse ou benefício dos grandes conglomerados de empresas. Na busca de uma mais efetiva justiça ambiental e social, criminalizou-se a pessoa coletiva e seus dirigentes, até por omissão, deixando-se, muitas vezes de criminalizar os funcionários subalternos, autênticos "peixes miúdos" que, não raramente, acabam por sofrer injusta imputação quando não poderiam agir doutra forma na estrutura da empresa.

Em razão desses novos paradigmas, necessátio se faz repensar o Direito Penale o Direito Processual Penal, adequando-se-os, principalmente, aos novos sujeitos trazidos ao polo passivo do processo criminal.

\section{EFETIVIDADEDA RESPONSABILIDADE PENAL DA PESSOAJURÍDICA NO DIREITO BRASILEIRO}

A responsabilidade penal da pessoa jurídica, realidade na Lei dos Crimes contra o meio ambiente, gradativamente vem se tornando efetiva. De um modo geral, as pessoas jurídicas tem acatado a sua responsabilização trazida pela Lei nº $9605 / 98$.

Há registro de diversas ocorrências de fatos, em tese constituindo crimes tipificados pela mencionada lei de proteção penal do meio ambiente, a respeito dos quais as pessoas jurídicas, aceitando a atribuição da autoria, tem efetuado transação penal, nos termos da Lei dos Juizados Especiais, a Lei n⿳909099/95, aceitando a imposição imediata de medida altemativa (restritiva de direitos ou multa) não havendo, em contrapartida, instauração de processo criminal com juízo de condenação e aplicação de pena. Dita transação é possível para determinadas infrações, consideradas de menor potencial ofensivo (contravençóes penais ou crimes com penas cominadas até dois anos, artigos 61 e 76 da Lei no $9099 / 98$ e artigo $2^{\circ}$ da Lei $\mathrm{n}^{\mathrm{O}}$ 10259/01).

Também se registram fatos, tipificados como crimes contra o ambiente, em que as pessoas jurídicas têm acordado a suspensão do processo, trazida para o direito brasileiro pela Lei dos Juizados Especiais, em seu artigo 89 (possível para os crimes a que cominada pena mínima não supetior a um ano). Em tal situação, oferecida denúncia, fica o processo suspenso, mediante condiçóes avençadas, transcortido o prazo da suspensão, cumpridas as condiçôes, constatada por laudo a reparação do dano ao ambiente, é declarada extinta a punibilidade.

Ditas medidas, além de propiciarem pronta solução aos casos, constituem, em nosso sentir, instrumentos de efetiva tutela ao ambiente, já que somente é possível a transação penal se houver prévia composição do dano causado ao meio ambiente, assim como na suspensăo do processo, conforme já apontado, para a declaraçấo da extinção da punibilidade é exigida a constatação por laudo da reparação do dano ao ambiente (artigos 27 e 28 da Lei n 9605/98).

Éde se observar que, dentre os crimes previstos na Lei n $9605 / 98$, apenas um não se enquadra, em razão das penas cominadas, dentre os que admitem transação ou suspensão do 
processo, qual seja, o de incêndio doloso contra mata ou floresta (artigo 41, "caput"). Assim, em sua grande maioria, os fatos acabam não sendo submetidos a processo e condenação no juízo criminal, restringindo-se àquelas altemativas, no mesmo juízo criminal, é bem verdade.

Registram-se, no entanto, casos de instauraçăo de processo criminal contra pessoas jurídicas, principalmente deconrentes do juizo de não suficiência daquelas alternativas (transação penal e suspensão do processo submetem-se também a outros requisitos, além da quantificação de pena cominada, que demonstrem suficientes ditas alternativas).

Alguns casos já chegaram aos tribunais de segundo grau, dentre os quais, registra-se o Recurso Criminal 00.020968-6, julgado pela Primeira Câmara Criminal do Tribunal de Justiça de Santa Catarina, sendo relator o Desembargador Solon d'Eça Neves, que, dando provimento ao recurso interposto pelo Ministério Público, determinou o recebimento de denúncia contra a empresa Agropastoril Bandeirante Ltda. pelos crimes de poluição previstos nos artigos $54, \S$ $2^{\circ}, \mathrm{V}$ e 60 da Lei $\mathrm{n}^{\circ}$ 9605/98. Haviam sido denunciados tanto a empresa quanto as pessoas físicas seus sócios, tendo o juiz de primeiro grau rejeitado a denúncia relativamente à pessoa jurídica, a recebendo tão somente quanto às pessoas físicas. Por unanimidade, a Câmara acatou orecurso, admitindo expressamente a responsabilidade penal da pessoa jurídica, com a seguinte ementa: "Completamente cabível a pessoa jurídica figurar no pólo passivo da ação penal que tenta apurar a responsabilidade criminal por ela praticada contra o meio ambiente".

Outro caso significativo tramita na Justiça Federal do Brasil. Trata-se de ação penal 2000.70.00.019440-4, na 2a. Vara Federal Criminal de Curitiba, Paraná, em que foi denunciada a Petrobrás-Petróleo Brasileiro S/A, pessoa jurídica de direito privado e alguns de seus dirigentes, pelo delito de poluição previsto no artigo 54 da Lei dos Crimes contra o ambiente. Houve interposição de mandado de segurança criminal, visando o trancamento da ação penal contra a pessoa jurídica, tendo sido denegado, neste aspecto, por unanimidade pela Sétima Turma do Tribunal Regional Federal da 4a. Região.

Destaca-se, da ementa do julgamento: "Crime contra o meio ambiente. Responsabilidade Penal da Pessoa Jurídica. Possibilidade. Evolução histórica do conceito de pessoa jurídica. Passagem da criminalidade individual ou clássica para os crimes empresariais... . Imputação penal às pessoas jurídicas. Capacidade jurídica de ter causado um resultado voluntariamente e com desacato ao papel social imposto pelo sistema normativo vigente. Possibilidade da pessoa jurídica praticar crimes dolosos, com dolo direto ou eventual, e crimes culposos. Culpabilidade limitada à manifestação de vontade de quem detém o poder decisório". (Mandado de Segurança 2002.04.01.013843. O/PR).

Em 18 de abril de 2002 foi proferida sentença, a primeira, ao que consta, lançada em nosso país, condenando pessoa jurídica por crimes contra o meio ambiente. Trata-se de decisão do magistrado Luiz Antonio Bonat, Juiz Federal, da la. Vara em Criciúma, Santa Catarina, no processo 2001.72.04.002225-0 que condenou a empresa A.J. Bez Batti Engenharia Ltda. e seu diretor pelos crimes previstos nos artigos 48 (impedimento de regeneração de vegetação) e 55 (extração indevida de recursos minerais) da Lei $n^{\varrho} 9605 / 98$, em concurso formal. 
Mais recentemente ainda, em 6 de agosto de 2003, o Tribunal Regional Federal da 4a. Regiäo, julgando a apelaçăo criminal $n^{\circ} 2001.72 .04 .002225$-0/SC, por decisão unânime, sendo relator o Desembargador Federal Élcio Pinheira de Castro, manteve, por unanimidade, a sentença condenatória. Trata-se, portanto, ao que tudo indica, da primeira condenação de pessoajurídica em segundo grau de jurisdição proferida no Brasil, tendo o acórdão já transitado en julgado, sendo, pois, definitiva a decisão. Configura, assinn, significativo precedente.

Registram-se, atualmente, várias outras decisóes, tanto de primeiro quanto de segundo grau, no sentido da admissibilidade da responsabilização criminal da pessoa coletiva por delitos contra a ambiente. Ainda, outras sentenças com juizos condenatórios foram proferidas näo se tendo, todavia, notícia de já terem sido decididas em segundo grau de jurisdição.

\section{DIFICULDADES JURÍDICO-OPERACIONAIS. ALGUMAS QUESTÕES PROCESSUAIS}

A Lei $9605 / 98$, ao inovar no direito penal brasileiro com o reconhecimento da coresponsabilização criminal entre a pessoa jurídica e a pessoa natural, como está no artigo $3^{\circ}$ e seu parágrafo único, apresenta, no entanto, lacuna ao não explicitarnormas processuais ou procedimentais sobre esta nova criminalização. No tocante aos aspectos processuais, contém apenas três dispositivos que dizem também com matéria penal, quais sejam, o artigo 26 que determina seja sempre pública incondicionada a ação penal, o artigo 27 , regulando regras especiais para a transação penal e o artigo 28 tratando da suspensão do processo determinando procedimentos especiais à declaraçăo da extinção da punibilidade na busca de efetiva constatação da reparaçáo do dano ao meio ambiente.

Em decorrência desta não previsão expressa de regras ptocedimentais, dificuldades jurídicas operacionais vêm surgindo na efetivação da nova responsabilização em matéria penal. De lege ferenda, seria conveniente a explicitação de algumas regras de processo e procedimento a facilitar a operacionalização desta nova via de proteção penal ao meio ambiente, já que, como sabemos, as mais expressivas degradaçôes ambientais são praticadas no interesse e benefício das pessoas jurídicas, através de sua por vezes extremamente complexa estrutura. Quem sabe, aproveitando, ao menos em parte, o modelo francês que editou uma "lei de adaptaçăo" trazendo regras de processo penal específicas à pessoa jurídica, como parece sugerix, dentre nós, Tupinambá Pinto de Azevedo.

No atual contexto, todavia, não se apresentam autênticos e insuperáveis óbices que inviabilizem a efetivação da responsabilidade criminal da pessoa jurídica no direito ambiental penal brasileiro, como muito bem destacam Ada Pellegrini Grinover ${ }^{4} \mathrm{e}$ Walter Claudius Rothenburg. ${ }^{5}$. Por integração pelas normas e princípios gerais já existentes no sistema junídico penal brasileiro poderão, perfeitamente, serem solucionadas ditas dificuldades e aparentes óbices.

\footnotetext{
${ }^{3}$ Azevedo, Tupinambá Pinto de. Aspectos processuais da Lei n.9605/98, em Direito Ambiental na visão da Magistratura e do Ministério Público, Del Rey 2003, pp. 361/407.

${ }^{4}$ Grinover, Ada Pellegrini, Aspectos processuais da responsabilidade penal da pessoa juridica, em Responsabilidade Penal da Pessoa Juridica e medidas provisórias e Direito Penal, RT, 1999,pp. 46/50 ${ }^{5}$ Rothenburg, Walter Claudius, em Responsabilidade Penal da Pessoa Juricica e medidas provisórias e Direito Penal, RT, 1999.pp.153/158
} 
A seguir, abordaremos algumas destas questöes, ditas processuais, que tem surgido na operacionalização da efetividade da responsabilidade criminal da pessoa coletiva, trazidas como alegados óbices por parte da doutrina e pareceres de consultores contratados pelas pessoas jurídicas, referindo também a jurisprudência sobre a matéria.

Ditas questóes dizem com:

a) a existência ou não de concurso necessário entre a pessoa física e a jurídica, o interesse e benefício da última como requisito à sua responsabilização e os seus conseqüentes reflexos na elaboração da denúncia pelo agente do Ministério Público

b procedimento aplicável

c) representação em juízo; na citação e intinaçãa; na composição do dano, na transação penal e na suspensão do processo

d) o interrogatório da pessoa jurídica: indicação ou não de preposto?

e) aplicação da penae seus reflexos na sentença; dosimetria; princípios "nulla poena sine lege" e daindividualização da pena.

f) execução da pena não cumprida pela pessoa coletiva; multa; testritivas de direitos e prestação de serviços à comunidade.

\subsection{DENÚNCIA}

\subsubsection{Concursonecessário?}

Uma das dificuldades com que tem se deparado os agentes do Ministério Público, na elaboração da denúncia en caso de crimes contra o ambiente praticados através da pessoa jurídica tem sido a alegada existência de concurso necessário entre a pessoa jurídica e a pessoa natural, de modo que, indispensavelmente, deverá a peça acusatória explicitar a(s) pessoa(s) físicas co-attora $(\mathrm{s})$ da pessoa juńdica, oferecendo também denúncia contra as pessoas naturais, sob pena de rejeição.

O concurso de agentes no crime, sabidamente, pode ser necessário ou eventual. Quando a descrição do tipo de um delito contiver, dentre seus elementos, a pluralidade de agentes, como no caso do crime de quadrilha ou bando (artigo 288 do Código Penal), estaremos frente ao concurso necessário de agentes, já que integrante do tipo. Concurso eventual haverá nos demais crimes que, embora podendo ser executados por uma pessoa, eventualmente, poderão ser realizados por mais de um agente, seja como co-autor ou partícipe.

Os tipos penais descritos na Lei $9605 / 98$ são, obviamente, delitos de autoria singular, admitindo eventual concurso de agentes, como a grande maioria dos crimes.

No tocante à pessoa jurídica, todavia, como explicita o artigo $3^{\circ}$ da mencionada leí, está prevista a co-responsabilização entre a pessoa jurídica as pessoas físicas, autoras, co-autoras e partícipes.

No "caput" do dispositivo legal, previsto como requisito da responsabilidade criminal da pessoa coletiva que a infração "seja cometida por decisão de seu representante legal ou contratual, ou de seu órgão colegiado". Sempre, pois, haverá uma ou mais pessoas 
naturais deliberando pela pessoa jurídica e, pois, concurso de agentes entre a última e a (s) pessoa(s) física(s). Aquele ou aqueles que deliberarem no interesse e benefício da pessoa jurídica, serão seus co-autores, segundo a teoria do domínio do fato, ou meros mandantes segundo a teoria formal ou da tipicidade que restringe a autoria (e a coautoria) à execução da figura típica.

Outros conconentes, eventualmente, poderão surgir, comoa(s) pessoa(s) física(s) que, não sendo quem deliberou pela pessoa jurídica, contribuiu de qualquer sorte para o crime contra o ambiente, como, exemplificativamente, os empregados que executaram as tarefas degradadoras de poluição em níveis tais a configurar o tipo poluiçăo previsto no artigo 54 da Lei $9605 / 98$, desde logicamente, que presentes outros requisitos à sua imputação, dentre eles, a exigibilidade de conduta diversa. Trata-se, aqui, do concurso de agentes previsto no parágrafo único do mencionado artigo $3^{\circ}$.

Assim, embora não seja elemento dos tipos penais contra o meio ambiente, em se tratando de atividade através e no interesse da pessoa jurídica, pressuposto estará o concurso de agentes com a pessoa natural que deliberou pela pessoa coletiva. Sendo requisito da responsabilização, deverá estar explicitado e natrado con suas circunstâncias fáticas na denúncia.

Desta forma a jurisprudência vem se manifestando, reconhecendo inépcia da peça acusatória quando não permite concluir que o delito foi conetido por decisão de representante legal ou contratual, ou de órgão colegiado da empresa acusada (MS. 34440/8, 3a. Câmata Criminal do Tribunal de Alçada Criminal de SP,MS. 2001.02.01.046636-8, 5a. Turma, Tribunal Regional Federal da 2a. Região). Inclusive, no mesmo sentido, decisão do Superior Tribunal de Justiça, RE331929-SP(2001/00866677-9).

Não significa, no entanto, que sempre deverá a denúncia incluir dentre os imputados as pessoas físicas, mesmo aquelas que teriam deliberado pela pessoa jurídica. Isso porque, às vezes, embora evidenciada a concorrência, não se consegue apurar a $(s)$ pessoa(s) física (s) que contribuíram. Dita conclusão tanto se aplica aos concorrentes previstos no parágrafo único do artigo $3^{\circ}$ da Lei 9605/98, como eventuais empregados que executaram as tarefas que contribuíram ao crime, quanto aos previstos no "caput" do mesmo dispositivo legal, ou seja, aquele(s) que deliberaram pela pessoa jurídica. Tal poderá ocorrer quando não identificados aqueles que deliberaram, por exemplo, dentre os sócios membros de órgão colegiado em reunião com votação secreta em decisão não unânime, cono muito bem aponta Tupinambá Pinto de Azevedo'.

Assim, o que a denúncia deverá conter, necessariamente, seráa deliberação por quem de direito no seio da pessoa jurídica, incluindo na imputação ditas pessoas físicas quando identificadas. Acaso não precisamente apuradas suas identificaçóes, deverá a referida circunstância ser explicitada na peça acusatória que, assim, atenderáo requisito da lei penal ambiental, denunciando a pessoa jurídica, fundamentando seus pressupostos, mas deixando de denunciar outros concorrentes eventualmente näo aputados.

6 Obra citada, pp.366 e 399 
O mesmo poderá ocorrer nos chamados crimes de concurso necessário de agentes, como o do artigo 288 do $\mathrm{CP}$, no concurso eventual de agentes no furto ou roubo, hipóteses em que, embora evidenciado o concurso (necessário ou eventual), narrado na peça acusatória, não apurado algum ou alguns dos sujeitos ativos. Não deixará, por isso, de ser admitido o concurso, a qualificadora ou a majorante, respectivamente. Da mesma sorte, reitere-se, comprovada a deliberação pela pessoa jurídica, mas não identificada(s) pessoa(s) física (s) concorrente(s), poderá, perfeitamente, ser denunciada a pessoa jurídica, já que presente requisito legal à sua imputação.

\subsubsection{Interesse ou beneficio da pessoa jurídica}

Outro pressuposto à responsabilização criminal da pessoa jurídica, segundo a Lei dos Crimes contra o Ambiente, é que a infração seja cometida no interesse ou benefício da pessoa coletiva (artigo 30, "caput").

Assim, a peça acusatória deverá explicitar os requisitos benefício e/ou interesse da pessoa jurídica. De regra, qualquer conduta no exercício regular da atividade de uma empresa, por exemplo, será no seu interesse ou benefício. Todavia, poderá determinada conduta ser exercitada sem deliberaçăo por quem de direito, ou com excesso de mandato ou até contrariamente aos interesses da empresa. Em tais casos, ausente pressupostolegal, não será denunciada a pessoa jurídica e, tăo somente, a pessoa ou as pessoas físicas responsáveis.

Interessante citar aqui precedente jurisprudencial em mandado de segurança relatado pelo Desembargador Federal Vladimir Passos de Freitas: "As pessoas jurídicas podem ser processadas por crime ambiental, todavia, a denúncia deve mencionar que ação ou omissão foi fruto de decisão de seu representante legal ou contratual, ou do seu órgão colegiado, ainda que esta decisão tenha sido informal ou implícita. (parte da ementa no MS. 2002.04.01.054936-2/SC) No corpo do acórdão sustentado que a vantagem (interesse ou beneficio da entidade) pode estar implícita nos atos da diretoria, não sendo necessário que tenha sido deliberada enn reuniāo e registrada em ata, até porque isso seria praticamente impossível de ocorrer. Todavia, mesmo implícita, deve ser apontada na denúncia.

Ainda, de valia recomendação da Subprocuradora-Geral da República, Dra. Ela Wiecko V. de Castilho, no parecer lançado no RE331929-SP (2001/0086677-9), STJ: "Indiscutivel a desnecessidade de ato formal. Todavia, necessária a indicação mínima de tomada de posição. Por exemplo: orientação para contenção de despesas, para compra de material de baixa qualidade, a demissão de funcionários qualificados e contratação de inexperiente, a instalação de uma fábrica sem o licenciamento ambiental, etc.".

De se destacar também o constante no ítem 42 da Ementa no acórdão do MS. 2002.04.01.013843-0/P que foi relatado pelo Desembargador Federal Fábio Bíttencourt da Rosa do Tribunal Regional Federal da 4a. Região: "O art.30 da Lei 9.605/98 condiciona a responsabilidade criminal da empresa ao fato de ter sua direção atuado no interesse ou beneficio de sua entidade. O que se deve examinar para saber se o tipo penal 
do art. $3^{\circ}$ da Lei $9.605 / 98$ acabou por ser subsumido é analisar o conteúdo da decisão do órgão diretivo. Se ela foi tomada no desenvolvimento empresarial e para garantir o sucesso dele, não há interesse individual do gerente na decisão, mas da sociedade. Logo, a mesma surgiu para satisfazer o interesse da garantia do resultado da produção. Esse proveito para o sucesso da empresa pode ser intencional (dolo) ou fruto de negligência (culpa)."

Em termos de Direito Ambiental Penal, estamos frente a novos paradigmas, dentre eles a responsabilização criminal da pessoa jurídica. Assim, o agente do Ministério Público deve estar atento às peculiaridades desses novos direitos, a exigirem mecanismos procedimentais especiais, de modo que se recomendam denúncias bem mais arrazoadas, bem mais detalhadas, explicitando todos os requisitos àquela responsabilização, autêntico novo paradigma. Assim, deverá arrazoar como pressupostos: a) deliberação por quem de direito, inclusive a forma da decisăo, b) interesse ou benefício da pessoa jurídica. c) nartar a conduta do (s) executor (es), com a qual se confundirá a atividade da pessoa jurídica já que aqueles executam conduta por esta, d) incluir as pessoas físicas identificadas como co-autoras ou partícipes.

\subsection{PROCESSO}

As garantias constitucionais do processo aplicam-se não somente às pessoas naturais quanto às jurídicas. Como bem observa Ada Pellegrini Grinover, "embora historicamente relacionadas à proteção do indivíduo submetido à persecução penal, seu valor não pode ser menosprezado quando se admite hoje a responsabilizaçăo penal da pessoa juridica, pois se a simples instauração do processo penal sempre representou um dos maiores dramas para a pessoa humana, não são menores as repercussões que uma acusação criminal dirigida a uma empresa pode acarretar ao normal desenvolvimento de suas atividades e, sobretudo ao seu conceito e de seus dirigentes e funcionários no seio da comunidade"?

Assim, aplicam-se às pessoas jurídicas e não somente às físicas as regras constitucionais bem como as processuais gerașs, num autêntico processo de integração das normas do ordenamento juńdico como um todo. Portanto, presunção de inocência, devido processo legal, contraditório, ampla defesa, duplo grau de jurisdição, dentre outras, são garantias também da pessoa coletiva.

\subsubsection{Procedimento aplicável}

Conforme já destacado, não existe, na Lei $9605 / 98$ qualquer tegra explicitando o procedimento aplicável em caso de ser processada a pessoa jurídica por crime contra o meío

\footnotetext{
7 Grinover, Ada Pellegrini, Aspectos processuais da responsabilidade penal da pessoa juridica, texto ampliado e revisto, em palestra proferida no 3o.Curso de Direito Ambiental Penal do Instituto $O$ Direito por um Planeta Verde, sob o titulo: "A pessoa juridica como acusada no processo crimina: aspectos processuais, inédito, pp.1/2
} 
ambiente. Dita falta de previsão tem levado alguns a sustentarem ter sido ferido o princípio constitucional do devido processo legal.

Todavia, aplicam-se, por integraçâo, as regras e garantias processuais gerais, de modo que os procedimentos aplicáveis em caso de processo contra a pessoa jurídica serão os ditos comuns, ordinário ou sumário, conforme as penas cominadas nos tipos incriminadores, pelas normas do Código de Processo Penal (sempre subsidiárias como explicita o artigo 79 da Lei $9605 / 98$ ) e o procedimento sumaríssimo das Leis dos Juizados Especiais Criminais em caso de infração de menor potencial ofensivo. Inclusive, com as regras especiais previstas nos artigos 27 e 28 da Lei $9605 / 98$ quanto à transação penal (exigindo prévia composição do dano ambiental) e à suspensão do processo (determinações específicas para a constatação da reparação do dano ambiental como condição à extinção da punibilidade).

Nenhuma dificuldade se nos afigura em tal sentido, sendo de se destacar útil a unifornização de procedimentos à pessoa natural e à pessoa jurídica, tendo em vista a ocorrência de concurso de agentes em crimes contra o meio ambiente, consoante já analisado anteriormente. Assim vem se orientando a doutrina grandemente majoritária ${ }^{9}$. Assim também a jurisprudência, inclusive em segundo grau de jurisdição (TRF da 2a. Regiăo, MS 2002.02.0104663-8, voto da relatora Desembargadora Federal Vera Lucia Lima, Tribunal de Alçada Criminal de São Paulo, HC 351992/2, Ementa 111229, tese vencedora do Dr. Lagastra Neto)

É bem verdade que seria aconselhável a edição de algumas regras especiais, mesmo que num procedimento comum para as duas espécies de acusados, de modo a esclarecer dúvidas em relação a determinados aspectos, como a representação em juízo, a citação, intimação, interrogatório, aplicação e execução das penas. Todavia, não fica obstaculizado o processo.

\subsubsection{Representação em juízo}

Nossa legislação processual penal, mesmo a Lei $9605 / 98$, não contém dispositivo sobre a representação da pessoa jurídica no juízo criminal. Preferível o tivesse feito e, de lege ferenda venha a fazê-lo, quem sabe seguindo as linhas gerais do modelo francês que explicita o representante legal na época das investigações (e não do delito) que a representará em todos os atos do processo, sendo designado pelo Tribunal de Grande Instância um representante no caso de a persecução penal pelos mesmos fatos ou conexos for também contra o representante legal.

\footnotetext{
* Schecaira, Sérgio Salomão, Responsabilidade Penal da Pessoa Jurídica, 2a. edição ampliada, Editora Método, pp.166/172

${ }^{9}$ dentre outros, Ada Pellegrini Grinover (obras citadas, p.48, item 4 e p.9, item 6 , respectivamente), Walter Claudius Rothenburg (obra citada, p.156), Tupinambá Pinto de Azevedo(obra citada, pp.362/ 363), Edis Milaré, (Direito do Ambiente. RT, 200, p.453)
} 
Enquanto tal não oconra em nosso país, no entanto, por integraçăo das normas do nosso ordenamento jurídico, a representação em juízo será regulada pelo Código de Processo Civil, de aplicação subsidiária, artigo 12, incisos VI e VIII, ou seja, por quem os seus estatutos designarem ou, na falta, por seus diretores e a pessoa jurídica estrangeira pelo seu gerente, representante ou administrador de sua filial, agência ou sucursal aberta ou instalada no Brasil ${ }^{10}$. Admitida a responsabilização criminal da pessoa jurídica de direito público, o que não é questăo resolvida frente nosso ordenamento jurídico, dependendo de interpretação, a representação será na forma do inciso I do mesmo artigo 12, ou seja, por seus respectivos procuradores.

Algumas questoes processuais devem anda ser mais de tidamente examinadas sobo aspecto da representação em juízo, em especial na citação, intimação, composição do dano, transação penal e suspensão processo.

\subsubsection{Citação e intimação da pessoa jurídica}

A citação e a intimação da pessoa jurídica será feita por intermédio de seu representante legal, na forma já explicitada, ou seja, de conformidade com o artigo 12 do CPC, recém examinado. Admitida a responsabilidade penal da pessoa jurídica de direito público, a citação da União será feita consoante estabelece a Lei Complementar 73, de 10.2.1993".

No mais, a citação da pessoa juridica obedecerá as regras do processo penal, ou seja, artigos 531 e seguintes do Código de Processo Penal e das Leis dos Juizados Especiais Criminais. Será pessoal e por mandado, expedindo-se precatória quando estiver o representante fora do território da jurisdição em que tramita o processo. Poderá ser por edital nas hipóteses dos artigos 361 a 363 do CPP. Já nos Juizados Especiais Criminais não é admitida a citação por edital. Não será possivel, outrossin, citação pelo correio.

As intimações, sempre através de representante, obedecerão ao Código de Processo Penal e as Leis dos Juizados Especiais Criminais, podendo, no último caso, ser feitas por qualquer meio idôneo de comunicação como permite o artigo 67 de Lei 9099/95' inclusive meio eletrônico trazido pela Lei dos Juizados Especiais Federais para as infrações de menor potencial ofensivo, aplicável também, por analogia, aos Juizados Especiais Estaduais.

\footnotetext{
${ }^{10}$ Grinover, Ada Pellegrini, obra citada p.47)

"Conforme artigo 35, nos processos da competêncla privativa do STF, através do Advogado-Geral da Uniäo, do Procurador-Geral da União em caso de competência originária de tribunais superiores, nos demais tribunais através do procurador-Regional da União e, na competência dos juizos de primeiro grau, através do Procurador-Chefe ou Seccional da Fazenda Nacional

12 Lel 9099/95, artigo 67: "a intimação far-se-á por correspondência, com aviso de recebimento pessoal ou, tratando-se de pessoa juridica ou firma individual, mediante entrega ao encarregado da recepção, que será obrigatoriamente identificado, ou, sendo necessário, por oficial de justiça, independentemente de mandado ou carta precatórla, ou ainda por qualquer meio idôneo de comunicação"
} 


\subsubsection{Representação na composição do dano, na transação penal e na suspensão do} processo

Em se tratando de infração penal de menor potencial ofensivo, sendo que a maioria dos crimes prevista na Lei $9605 / 95$ se enquadra na classificação, será admissível composição do dano e transaçāo penal, sem instauração de processo criminal e declaração de extinção da punibilidade, composto o dano e cumpridas as medidas aplicadas na transação. Ainda, admissível a suspensão do processo tanto nos delitos de menor quanto nos de "médio potencial ofensivo", no que abarcada a quase totalidade das infrações contra o ambiente.

Há de se resolver a questão da representação da pessoa coletiva em tais situaçóes. Deverão ser exigidos poderes expressos para tais fins no mandato outorgado ao seu representante?

A Lei 10259/01, regulando os Juizados Especiais Criminais Federais contém dispositivos autorizando os representantes tanto das pessoas juridicas de direito público federal (artigo 10) quanto das de direito privado (artigo 11, parágrafo único) a conciliar e transigir, contendo o último dispositivo legal menção expressa aos artigos 71, 72 e 74 da Lei 9099/95, abarcando, portanto, não só a composição de danos como também a transação penal.

Ditas determinações deven ser aplicadas também aos Juizados Especiais Criminais Estaduais, por isonomia e analogia.

Assim, mesmo ausente poderes especiais no mandato outorgado, autorizadas legalmente aos representantes a composição e a transação penal em nome e no interesse da pessoa jurídica autora de fato previsto como infraçăo penal de menor potencial ofensivo.

Relativamente à suspensão do processo, embora trazida pela Lei $9099 / 95$ que instituiu os Juizados Especiais Criminais no Brasil, não integra o procedimento especial da mencionada lei, aplicável tão somente às infrações de menor potencial ofensivo. É instituto cabível apenas nas infrações penais com pena mínima cominada não superior a dois anos, conhecidas como de "médio potencial ofensivo".

Como já analisado, a Lei 10259/01, aplicável por isonomia também aos Juizados Especiais Criminais Estaduais, confere poderes apenas para a composição dos danos e para a transação penal, referindo-se expressamente aos artigos 71, 72 e 74 da Lei $9099 /$ 95. Năo há qualquer menção ao artigo 89 da última lei que trouxe para o direito penal brasileiro a suspensão do processo.

Assim, entendo que, para a suspensão do processo conveniente a exigência de poderes expressos ao representante da pessoa jurídica.

É de se destacar que a representação da pessoa coletiva para os atos de composição e transaçăo penal poderá ser conferida a quem não seja seu representante legal, exigindo-se, então, na forma do artigo 10 da Lei 10259/01, designação por escrito, bastando mandato genérico. Para a composição dos danos e a transação penal, os poderes estão conferidos pela lei (artigo 11 , parágrafo único), independentemente de expressa menção no mandato. Já para a suspensão do processo, a procuração deverá conter explícitos poderes, sob pena de inviabilizado o ato ${ }^{13}$.

Exame a parte merece a representação da pessoa coletiva no interrogatório.

${ }^{3}$ Neste sentido, Tupinambá Pinto de Azevedo, obra citada, pp.374/376. 


\subsubsection{Interrogatório da pessoa jurídica. Indicaçăo de preposto?}

\section{Quem será interrogado pela pessoa jurídica? Não há, em nosso direito processual} penal qualquer regra específica a respeito, o que convém de lege ferenda seja tratado por nosso legislador, como feito no sistema francês.

Como já vimos, o representante legal da pessoa jurídica será o indicado pelo artigo 12 do $\mathrm{CPC}$, de aplicação subsidiária e, pois, quem, de regra, será interrogado em nome da pessoa coletiva. Alguns problemas, no entanto, poderão ocorrer, como no caso de uma empresa de grande porte com atuação em todo o território nacional indicando seus estatutos ou contrato social, que o representante será seu presidente, pessoa extremamente atarefada, viajando constantemente pelo paŕs e exterior: Por vezes, inviabilizado poderá até restar o ato, noutras de nenhuma utilidade à apuração dos fatos e até à defesa da empresa ré, bastando prever-se a hipótese de o representante estar totalmente alheio aos fatos imputados. Poderá, então, ser indicado procurador que tenha ciência dos fatos para ser intertogado em representação à ré?

Acaso respondida negativamente dita questão, entendendo-se que somente o representante legal é quem deverá ser interrogado pela pessoa jurídica, outro problema poderá se apresentar, na hipótese de o mesmo representante ser tanbém réu no processo, como co-autor ou participe, poderá ele ser interrogado nas duas qualidades? Ese as defesas, da pessoa jurídica da natural forem colidentes?

A questão é difícil e não pacificamente solucionada pela doutrina e jurisprudência.

Tupinambá Pinto de Azevedo, o primeiro, cremos, a escrever sobre o tema, tăo logo em vigor a novel responsabilização criminal da pessoa jurídica, com a Lei 9605/98, a quem homenageamos neste trabalho, assim se posiciona: "Não vemos impedimento a que esses representantes outorguem procuração a terceiros, para que compareçam a juizo e falem em none da empresa ré. Há conveniência de que o representante, submetido a interrogatório, tenha ciência direta dos fatos imputados". Manifestou-se pela aplicação subsidiária da Consolidação das Leis do Trabalho, com indicação de preposto ${ }^{14}$.

No mesmo sentido de admissibilidade de indicação de mandatário para o interrogatório também se pronunciou Walter Claudius Rothenburg, na linha do seguimento do sistema francês ${ }^{15}$.

No entendimento oposto, istoé, pela não possibilidade de indicação de pessoa física a ser interrogada em nome da jurídica, substituindo o gestor, revendo posição sua anterior, se manifestou a ilustre professora Ada Pellegrini Grinover, forte na fundamentação de que sendo o interroga tório essencial e prioritariamente meio de defesa, somente o gestor poderá ser interrogado pela pessoa jurídica ${ }^{16}$.

\footnotetext{
${ }^{14}$ Pessoa Jurídica: ação penal e processo na lei ambiental, Revista de Direito Ambiental,12/120 e Aspectos processuais da Lei n.9605/98, em Direito Ambiental na visăo da Magistratura e do Ministério Público, Del Rey, 2003, pp.376/377

${ }^{15}$ obra citada, pp.154/157

${ }^{16}$ Grinover, Ada Pellegrini, Aspectos processuais da responsabilidade penal da pessoa juridica, texto ampliado e revisto, em palestra proferida no 3o.Curso de Direito Ambiental Penal do Instifuto O Direito por um Planeta Verde, soi o titulo: "A pessoa juridica como acusada no processo criminal: aspectos processuais, irédito, pp.10/12
} 
Interessante precedente jurisprudencial temos no MS2002.04.01.013843-0-PR, impetrado por empresa nacional de grande porte inconformada com a decisão de primeiro grau que indeferiu pedido de indicação de preposto para o ato processual único e exclusivo de prestar interrogatótio em nome da pessoa jurídica. Postulou, então, indicação de preposto que tenha conhecimento do fato e cujas declarações a obrigarão, reconhecendo-se direito líquido e certo daré, sustentando ser o interrogatório meio de prova e instrumento de defesa sem forma definida na Lei $9605 / 98$, aplicáveis, por analogia, os princípios consagrados na legislação processual civil e trabalhista, com base no artigo $3^{\circ}$ do CPP.

Orelator, Desembargador Federal José Luiz B. Gernano da Silva, neste aspecto, concedeu liminarmente a ordem para que rosse a impetrante, pessoa jurídica, interrogada na pessoa de preposto que indicar, que tenha conhecimento dos fatos. Éo que se denota do voto do relator, às folhas 16 e 17. Todavia, ficou, no julgamento final, pelo colegiado, vencido em parte, justamente neste único aspecto, o da representação em juízo para o interrogatório, prevalecendo a tese contrária, consoante voto do relator para o acórdão, Desembargador Federal Fábio Bittencourt da Rosa, forte na carga de defesa contida no interrogatório, sua precípua função.

Assimse manifestou orelator do voto vencedor: "O interrogatório, como se sabe, caracterizase como um ato de prova e de defesa. Revela o fato e todos os componentes a serem analisados no que se refere à imputação criminal. Uma prova acusatótia sem una confissão exige muito maior carga de convencimento do que outra que cortobora uma confissăo. Essa é uma evidência de que o intertogatório constitui prova. Por certo que não tem eficácia exclusiva, podendo até mesmo caracterizaro crime de auto-acusação falsa descrito no art.341 do Código Penal. Também contém eficácia de defesa o interrogatório, sendo esta a precípua função dele, por isso ficando obrigado o juízo a ouvir o interrogando em qualquer fase do processo, sob pena de lesão ao princípio da ampla defesa. O réu, ao falar em juízo, tem a oportunidade de esclarecer a situação fática, explicar os motivos de sua ação, revelar fatos desconhecidos em seu proveito, dar sua interpretação referentemente a provas já colhidas, etc." (item 39 da fundamentação da Ementa, fls. $57 \mathrm{e} 58$ do voto vencedor).

O mandado de segurança acabou por ser denegado integralmente, inclusive neste aspecto, sendo determinado o interrogatório pelo representante legal, no caso o atual dirigente.

Divididos, pois, os entendimentos doutrinários e jurisprudenciais.

Nossa posição:

Como bem destaca a professora Ada Pellegrini Grinover, no artigo citado, lamentavelmente ainda inédito, mas que será objeto de publicaçăo a ser promovida pelo Instituto O Direito por um Planeta Verde, o interrogatório tanto é fonte (eventual) de prova quanto meio de defesa.

Concordando com a posição de prevalência do meio de defesa e os reflexos que dali decorrem, direito ao silêncio, também de ser reconhecido à pessoa jurídica, já que ninguém pode ser obrigado a reconhecer a própria torpeza, confissão a refletir no julgamento e o exercício mesmo do direito de se defender inerente ao interrogatório, entendo que, de regra, a pessoa jurídica deverá ser interrogada por intenmédio de seu representante legal. Quem representa legalmente a pessoa jurídica é quem poderá por ela exercer defesa.

Todavia, também eficácia, embora relativa, como meio de prova, apresenta o intertogatório. Assim, que será útil à apuração dos fatos, à busca da verdade e também à própria 
defesa da pessoa jurídica, lhe seja possibilitado trazer aos autos pessoa capaz de, em seu nome, com conhecimento fático, melhor exercitar a defesa já no interrogatório. Poder-se-ia argumentar, neste último aspecto, que a pessoa jurídica poderia arrolat como testemunha quem indicaria como preposto, assim exercendo sua defesa. No entanto, en contraponto, se o rol de testemunhas for excedido, poderá haver risco de prejuízo à defesa.

Ademais, porque trazer ao processo para ser interrogado quem, declaradamente pela pessoa jurídica, nada trará de útil, seja à apuração da prova, seja ao interesse da defesa? Ainda mais se antevendo aquelas dificuldades de chamamento e deslocamento do representante de empresa de grande porte e com ampla atuação nacional que, depois de inúmeras e alongadas no tempo tentativas de chamamento, no interrogatónio acaba por revelar nada saber até porque, na época, não era o dirigente da empresa ou o sendo tampouco tinha ciência?

A solução nos parece ser a de admissibilidade de indicação de preposto, exigindo-se, no entanto, poderes expressos para interrogatorio exercício de defesa pessoal em nome da pessoa jurídica.

Aregra será, entäo, interrogatório pelo representante legal na época do ato do interrogatório, com possibilidade de indicação de preposto com conhecimento dos fatos, explicitando-se no mandato aqueles poderes.

Ese orepresentante legal for também réu no mesmo processo e pelo mesmo fato, colidindo as defesas da pessoa natural e da jurídica?

Há quem entenda que, em tal processo, a sociedade não será interrogada, a não ser que exista outro administrador integrante do colegiado, que não tenha sido acusado(MS 2002.0401.013843-0/PR, item 40 da Ementa, p.58 do acórdão vencedor/Relator, Des. Fábio Bittencourt da Rosa).

Pedindo vênia ao respeitável entendimento, penso que a pessoa jurídica sempre teráo direito de ser interrogada. Havendo conflito entre sua defesa e a do representante legal também réu, a solução seráo juiz proporcionar indique a empresa procurador com aqueles poderes expressos.

3.2.4. Sentença. Aplicação da pena: dosimetria. Princípio "nulla poena sine lege" e da individualização da pena

Há quen sustente ter a Lei 9605/98 ferido o princípio "nulla poena sine lege" porque os tipos penais descritos na mencionada lei especial não contém as penas aplicáveis à pessoa juridica, somente prevendo penas privativas de liberdade, apenas aplicáveis à pessoa natural por óbvio, além da multa sem referência quanto à última de quantitativos e critérios de fixação para a pessoa jurídica. Não há regras específicas de dosimetria da sanção para a pessoa moral, sendo que os artigos da dita parte geral da Lei dos crimes contra o ambiente ao preverem penas à pessoa jurídica não especificam seus quantitativos mínimo e máximo, como, exemplificativamente, no caso de prestação de serviços à comunidade consistente em execução de obras de recuperação de áreas degradadas e contribuições a entidades ambientais e culturais públicas ${ }^{17}$.

17 Schecaira, Sérgio Salomão, obra citada, pp.162/166). 
No tocante ao alegado princípio "nulla poena sine lege", entendo năo ferido pela lei ambiental penal. Uma norma para ser penal no sentido estrito, de norma incriminadora, por óbvio, deverá conter dois preceitos: o primário, a expressar a conduta proibida ou exigida, eo secundário, expressando a coercibilidade através da sanção a ser imposta a quem descumprir o preceito ptimário. Todavia, nem sempre preceito e sanção precisam estar num mesmo dispositivo legal, bastando lembrar as conhecidas normas ditas imperfeitas, mas que completas são no sentido de configurarem noma penal incriminadora, contendo num dispositivo de lei o preceito e noutro a sanção aplicável a quem descumprir aquele, como as previstas na Lei de Abuso de Autoridade, Lei $4898 / 65$ que, nos diversos incisos dos artigos $3^{\circ}$ e $4^{\circ}$ descreve os tipos e no artigo $6^{\circ}$, parágrafo $3^{\circ}$ prevê as sançóes penais aplicáveis.

O mesmo ocorre com a Lei $9605 / 98$ que, nos diversos artigos do capítulo $V$ descreve os tipos penais contra o meio ambiente, explicitando penas privativas de liberdade e multa para a pessoa natural nos mesmos dispositivos legaise, nos artigos 21 a 23 prevê as penas aplicáveis à pessoa jurídica (destaque-se que o artigo 24 , ao contrário do que alguns sustentam, não constitui pena, mas efeito da condenação, qual seja, a liquidação forçada).

A norma penal está no sistema, sobrepairando às leis, como bem orienta a consagrada teoria das normas de Binding. Assim, não há, na lei ambiental penal, normas sem sanção e não ferido aquele princípio.

No tocante ao prazo das sançôes aplicáveis à pessoa jurídica, somente a proibição de contratar com o Poder Público e dele obter subsídios, subvençōes ou doaçōes contém prazo máximo previsto legalmente, no caso, dez anos (artigo 22, parágrafo $\left.3^{\circ}\right)$. No tocante às dernais sançôes, realmente, não há expressa menção a prazos. Seria conveniente, sempre de lege ferenda fossem fixados legalmente prazos, o que conviria estabelecido nas normas gerais e nâo para cada tipo penal, de modo a afastar qualquer dificuldade com o princípio da individualização da pena. Todavia, entendo que, mesmo frente à legislação atual, dito princípio năo resta ferido. De regra, os prazos das restritivas de direitos e prestaçóes de serviços à comunidade não poderão ultrapassar o máximo cominado a cada delito como privativa de liberdade para a pessoa natural, como vern se orientando a jurisprudência (MS 2002.04.01.013843-0/PR).

Quanto à pena de multa, aplica-se o mesmo critério do Código Penal que, para a pessoa física também previu nos tipos genericamente multa, sem especificar quantitativos. Os limites da pena de multa são os fixados pela parte geral do Código Penal, aplicável subsidiariamente também às leis especiais, como explicitamente previu o artigo 79 da Lei 9605/98.

No tocante à dosimetria, tampouco dificuldade maior existe. As regras gerais em se tratando de crime contra o ambiente, serão as da lei especial com aplicação subsidiária do Código Penal. Assim, especificamente para a pessoa jurídica, o juiz, observando o artigo 68 do Código Penal, aplicará o sistema trifásico: considerando as circunstâncias ditas judiciais do artigo $6^{\circ}$ da Lei $9605 / 98$ combinadas com as do artigo 59 do Código Penal compatíveis coma pessoa jurídica, fixará a pena base. Em seguida, considerando as agravantes e atenuantes específicas da lei ambiental (artigos 14 e 15) com aplicação subsidiária das atenuantes e agravantes previstas no Código Penal desde que não incompativeis com as da Lci $9605 / 98$ (por 
exemplo, a reincidencia somente será agravante se em crime ambiental) estabelecerá a pena provisória. Finalmente, tendo en vista as causas de aumento e de diminuição compativeis, aplicará a pena definitiva.

Instrumentalizando-se as regras do concurso aparente de normas e os princípios da subsidiariedade e especialidade, não haverá dificuldades sérias na dosimetria da pena à pessoa coletiva assim como à pessoa natural.

3.2.5. Execução das penas não cumpridas voluntariamente pela pessoa jurídica. Multa. Restritivas de direitos. Prestação de serviços à comunidade.

Aplicada pena à pessoa jurídica, como proceder em caso de descumprimento? Cabível execução compulsória? Qual o juízo competente, o criminal ou o cível? Terá o Ministério Público legitimidade para promover a execução?

As penas aplicáveis à pessoa coletiva são, como explicita o artigo 21 da Lei 9605/98, multa, restritivas de direitos e prestação de serviços à comunidade.

Cumpre destacar que a prestação de serviços à comunidade, para a pessoa natural, é espécie de restritiva de direitos, enquanto para a pessoa jurídica constitui pena autônoma. Todavia, na sua essência, configura restritiva de direitos, pelo que deverá seguir a mesma sistemática.

Não cumpridas pela condenada as restritivas de direitos e a prestação de serviços à comunidade, não poderão, como ocorre com a pessoa natural e determina o parágrafo $4^{\circ}$ do artigo 44 do Código Penal, ser convertidas em privativa de liberdade, obviamente, pela natureza mesma da pena incompatível com a pessoa coletiva.

Constituem autênticas obrigaçöes de fazer e como tais poderão ser executadas compulsoriamente, sob pena de ineficácia da decisão judicial. Não perdem, todavia, sua natureza de pena criminal e como tal deveráo ser executadas no juízo criminal, sendo o Ministério Público competente para promover a execução. O rito a ser impresso, na ausência de legislação específica, o que também convém seja tratado de lege ferenda, será o da legislação processual civil.

No tocante à multa, o artigo 51 do Código Penal, sempre de aplicação subsidiária, determina que, transitada em julgado a sentença condenatória, será considerada dívida de valor, aplicando-se as nomas da legislação relativa à divida da Fazenda Pública.

Em razăo do mencionado dispositivo legal, introduzido na legislação penal em 1996, existem entendimentos no sentido de que sua execução caberia à Fazenda Pública e não mais competente o juízo da execução criminal.

A propósito, os juízes de execução penal do Rio Grande do Sul, reunidos, deliheraram conjuntamente em tal sentido, entendendo não competentes as varas de execuçóes criminais e nem titular do impulso da pretensão executória o Ministério Público. Igualmente o Ministério Público por seus agentes junto à Vara de Execuçōes Criminais e às Varas da Fazenda Pública de Porto Alegre, bem como o Conselho dos Procuradores de Justiça e Promotores de Justiça 
com atuação na área criminal do Rio Grande Sul se manifestaram, através enunciado, pela ilegitimidade do Ministério Público para promover a execução da multa criminal.

Em 9 de julho de 2003 foi editado, pela Corregedoria Geral da Justiça do Rio Grande Sul, o provinento n $18 / 03$, em alteração à Consolidação Normativa Judicial, orientando no sentido da legitimidade ativa do Estado, através de seus procuradores, para a execuçáo da multa, sendo, no entanto, a competência para a execução das Varas Criminais (e não da Execução Criminal). Assim, curiosamente, a competênciaé da justiça criminal, mas o Ministério Público não é o legitimado ativo para a pretensão executória da multa.

Talvez por questões de ordem prática, fosse conveniente dita posição, visando desafogar as varas de execuções criminais bem como os agentes do Ministério Público tão assoberbados de feitos, principalmente nos grandes centros urbanos. Todavia, não concordamos com dito entendimento. A multa, mesmo con a nova re dação do artigo 51 do Código Penal, editado visando desautotizar conversão de multa em pena prisão até então prevista naquele dispositivo penal, não perde sua natureza de pena criminal e como tal deverá ser executada no juízo criminal, continuando competente para promover a execução o agente do Ministério Público. As alteraçöes que o artigo 51 sofreu foram, na verdade, no sentido de impedir a conversão em prisão (para a pessoa natural, por óbvio) e quanto ao procedimento da execução que seguiráo rito da lei do executivo fiscal, bem como no tocante às causas interruptivas e suspensivas da prescrição.

Em conclusão, o Direito Ambiental Penal apresenta como bem jurídico tutelado o meio ambiente, autêntico novo direito e um direito difuso por excelência, dizendo com a coletividade e com valores não só às presentes como às futuras gerações. Assim, há de trazer novos paradigmas ao Direito Penal, como a priorização da prevenção e da precaução, deixando de se ocupar apenas com o dano (que em muitas vezes poderá ser até irreversível) e a responsabilização criminal da pessoa jurídica e de seus ditigentes até por omissão, tendo em vista as atividades cada vez mais potencialmente ofensivas ao ambiente.

Em razāo destes novos paradigmas, novas posturas dos operadores de direito se mostram necessárias, com o desapego às rígidas e conservadoras regras do Direito Penal tradicional que não mais atendem às necessidades surgidas com a sociedade de risco e a priorização de direitos especiais e novos como o meio anbiente, autêntica riqueza a se preservar para ofuturo. 